\title{
VI. Memoir on the mineralogical geography of the environs of Paris
}

\section{Messr. Cuvier \& Messr. Brogniart}

To cite this article: Messr. Cuvier \& Messr. Brogniart (1810) VI. Memoir on the mineralogical geography of the environs of Paris , Philosophical Magazine Series 1, 35:141, 36-58, DOI: $10.1080 / 14786441008563015$

To link to this article: http://dx.doi.org/10.1080/14786441008563015

曲 Published online: 18 May 2009.

Submit your article to this journal \lceil

Џ Article views: 2

Q View related articles $\sqsubset$ 
ized! The imagination must then be supposed to act on a part of the fotus before such a part had any existence. The common opinion is, that monstrosity depends on original conformation of the ovum; nor is it by any means inteligible that a metamorphosis or annihilation of any part of the foetus can take place from an impression on the imagination of the parent.

I have said that Enceps's object in writing was not levity; but when I came to the tale of the cat and the kittens, my suspicions were somewhat roused. "A pregnant she cat" had its tail trodden upon, and lo! when she littered she had an even number of kittens; otherwise the surprising things that did happen, could not have happened - that " half of her kittens had their tails bent in the middle!". and that half had not. The circumstance which roused my suspicion was the gravity with which Enceps says " this fact (or rather this tale) seems to be very important, and to prove nearly to a demonstration, that the imagination of pregnant females has the power of acting on the bodily conformation of their young!!'”

As a medical man, I had reason to hope that the old prejudice of the perfection of the foetus being in anywise contingent on the imagination of the parent was at an end; and having long been a reader of your respectable Magazine, I could not observe Enceps's reasoning in favour of such a prejudice, without presuming that it was subject to animadversion.

$$
\text { I remain, sir, your humble servant, }
$$

December, 1809.

Chinurgicus.

VI. Memoir on the Mineralogical Geography of the Environs of Paris. By Messrs. Cuvier and Brogniart*.

$\mathrm{T}_{\mathrm{HE}}$ country in which Paris is situated is perhaps one of the most remarkable hitherto observed, from the succession of the various soils which compose it, and from the extraordinary remains of ancient organizations which it contains : myriads of sea shells, regularly alternated with fresh-water shells, form the principal mass : bones of terrestrial animals, entirely unknown even with respect to their genera, fill certain parts : other bones of species remarkable from their size, and the counterparts of which are only

- Annales du Mustem d'Histoire Naturelle, tome xi. p. 293.

found 
found in very distant countries, are scattered in the strata nearest the surface : a strongly-marked character of a great eruption proceeding from the south-east is imprinted on the forms of the eminences and the directions of the valleys : in short there is no district better adapted for making us acquainted with the final revolutions which put a termination to the formation of our continent.

This country has nevertheless been very little studied under this point of view; and although so long inbabited by many enlightened men, whatever has been written on the subject has been confined to some detacised fragments, and almost all of them are either exclusively mineralugical, without any regard to organized fossils, or purely geological, without reference to the position of these fossils.

A memoir of Lamanon, on the gypsums and their fossil bones, may perhaps form the only exception to this classification : we are bound, however, to acknowledge that the excellent description of Montmartre by M. Desmarets, the information given by the same author as to the basin of the Seine, in the Encyclopédie Méthodique, the mineralogical essay on the department of Paris by $\mathbf{M}$. GilletLaumont, the extensive researches on the fossil shells of the environs of Paris by M. Lamarck, and the geological description of the same district by $M$. Coupé, have been advantageously consulted, and have several times directed our steps.

We presume to think that the task of which we are about to present the class with a sketch, will not be without interest, notwithstanding the works above alluded to.

Four years ago we commenced our Jabours; and although we have persevered in them by making numerous excursions, collecting specimens and information from every quarter, we are far from thinking we have done enough, and we earnestly desire that our readers may not confound the abridgement which we are about to give, with the full details which we propose to publish. Some circumstances compel us to present this abridgement at this moment, and to assign a date * to such tedious and laborious researcbes, before the happy period at which we shall think them brought to a conclusion.

From the nature of their object, our sketohes were limited according to the nature of the soil, and not according to arbitrary divisions.

We thought it right therefore, in the first place, to de-

* This Mernoir was printed in Jan. 1809,-Eprt. C 3

termine 
termine the physical boundaries of the district which it was our object to study.

The basin of the Seine is separated for a long space from that of the Loire by an extensive high plain, the greater part of which vulgarly bears the name of Beauce, and the middle and driest part of which extends from the north-west to the south-east, over an extent of more than forty leagues, from Courville to Montargis.

This plain is bounded towards the north-west by a bigher, and in particular a more broken district, from which the rivers Eure, Aure, Ilon, Rille, Orne, Mayenne, Sarte, Huine, and Loire, arise. The highest part of this district is between Sees and Mortagnes, and which formerly composed the province of Perche, and a part of Basse-Normandie, and which now belongs to the department of the Orne.

The line of separation between Beauce and Perche passes close by the towns of Bonnevalle, Alluye, lliers, Courville, Pontgouin, and Verneuil.

On all other sides the plain of Beauce overlooks every surrounding district.

Its slope towards the Loire is not interesting to our subject.

The slope towards the Seine is divided into two inclinations, one of which on the west looks towards the Eure, and the other on the east looks towards the Seine.

The first proceeds from Dreux towards Mantes.

The other begins from the neighbourhood of Mantes, passes by Marly, Meudon, Palaiseau, Marcoussy, the Ferté-Alais, Fontainebleau, Nemours, \&c.

But it must not be concluded that these two inclined planes are straight or uniform; on the contrary, they are in all directions unequal and rugged, to such a degree that, if this vast plain were surrounded with water, its edges would furnish gulfs, capes, and straits, and would be every where surrounded by small islands.

In the same manner in our environs, the long mountain on which are situated the woods of St. Cloud, Villed'Avray, Marly, and Aluets, and which extends from St. Cloud to the confluence of the river Maulde in the Seine, would form an island separated from the rest by the strait in which Versailles is situated, the little valley of Sevres, and the great valley containing the park of Versailles.

The other mountain in the form of a fig leaf, on which are situated Bellevue, Mendon, the woods of Verriere, and those of Chaville, would form a second island separated 
from the continent by the valley of Bievre and that of the hills of Jouy.

But afterwards, from St. Cyr to Orleans, there is no longer any complete interruption, although the rivers Bievre, Ivette, Orge, Etampes, Essonne, and Loing, cut deeply into the continent on the east coast, while the rivers of Vesgre, Voise, and Eure, do the same towards the west.

The most rugged and uneven part of the surlace, and that which would furnish most islands, would be what is vulgarly called the Gâtinois Franģois, and particularly that part in which the forest of Fontainebleau is situated.

The slopes of this immense platform are generally very abrupt; and all the ravines which we find in them, as well as those of the vallev:, and the wells dug in the high parts, show that its physical nature is the same every where, being formed of one prodigious mass of fine sand which covers the whole surface, passing equally over all the other soils or inferior platforms which this great plain overlooks.

The edge of this platform towards the Stine, from the Maulde to Nemours, will therefore form the natural limit of the basin which we are about to examine.

From below its two extremities, $i . e$. towards the Maulde and a little beyond Nemours, immediately issue two portions of a platform of chalk, which extends in every direction and to a great distance, in order to form the whole of Haute Normandie, Picardy, and Champagne.

The interior edges of this great girdle, which pass from the east by Montereau, Sezanne, and Epernay; from the west by Montfort, Mantes, Gisors, and Chaumont, in order to approach Compiegne, and which form at the nortb-east a considerable re-entering angle which embraces the whole of the Laonnois, complete, together with the sandy coast now described, the natural limit of our basin.

But there is this great difference, that the sandy platform which comes from Beauce is higher than the others, and is consequently the most modern, and finishes completely the stretch of coast which we have marked; while, on the contrary, the platform of chalk is naturally more ancient and lower than the rest, only ceasing to appear outside of the girdle above mentioned; but so far from being at an end, it visibly sinks under all the other strata: we fand it in short wherever we dig sufficiently deep under the latter, and it even rises up in some places, piercing as it were through the other strata.

We may therefore conclude that the materials which sompose the basin of Paris, in the directions to which our C 4 inquiries 
inquiries were limited, have been deposited in a vast hollow or gulf, the bottom of which was of chalk.

This gulf perhaps formed a complete circle, or a kind of great lake; but we cannot ascertain this, in consequence of its edges on the south-west having been covered, as well as the materials of which they were composed, by the great sandy platform first inentioned.

We may add that this great sandy platform is not the only one which has covered the chalk; there are several in Champagne and Picardy, which, although smaller, are of a similar nature, and may have been formed at the same time. Like it, they are placed immediately over the chalk, in the places where the latter was so high as not to admit of its being covered with the materials of the basin of Paris.

We shall in the first place describe the chalk, the most ancient of the substances which we have in our environs, and conclude with the sandy platform, the most recent of our geological productions.

In the intermedium between these two extremes we shall speak of less voluminous but more varied substances, which had covered the great cavity of the chalk before the platform of sand was deposited on some of them.

These substances may be divided into two soils (étages).

The first (which covers the chalk wherever it was not sufficiently high, and which has filled the whole of the bottom of the gulf, ) is itself subdivided into two parts of equal level, and placed not upon one another, but end to end : viz.

The platform of siliceous lime containing no shells.

The platform of lime with coarse shells.

We are sufficiently well acquainted with the limits of this soil on the chalky side, because the chalk does not cover it; but these limits are marked in several places by the second seil, and by the great sandy platform which forms the third, and which covers a great part of the two others.

The second soil will be named gypso-marley.

It is not generally spread, but merely scattered from space to space, and as it were by spots; these spots also are very different from each other in thickness, and in the details of their composition.

These two intermediate soils as well as the two extreme soils are covered, and all the vacuities which they have left are partly filled, by a fifth sort of soil, mixed also with marle and silex, and which we call-fresh-water soil, because it abounds in fresh-water shells only. 
We have the honour to present the class with the first of a series of mineralogical charts, in which each kind of soil is coloured differently.

The sand is fawn-coloured; gypsum blue; shelly lime yellow; siliceous lime violet; chalk red colour; freshwater soil green streaked with white. We have here marked in plain green, the worn or alluvial sands which have not been tranquilly deposited, but brought from other quarters by currents; and in dark brown the peaty soils formed along the rivulets and round the pools of water.

This chart, one of the principal results of our travels, is complete in the coloured part, and we have only left uncoloured that with which we are not yet sufficiently acquainted.

Such are the great masses of which our district is composed, and which form the different strata. But on subdividing each stratum we may attain still greater precision, and obtain still more rigorous mineralogical determinations, which will give so many as ten distinct kinds of strata, of which we shall now present a rapid enumeration.

\section{Artrcle I. Formation of Chalk.}

Chalk forms in the environs of Paris, as in almost all those places where it has been observed, a mass in which the strata are frequently so indistinct that we are almost inclined to doubt whether it was formed by beds, if we did not see these beds interrupted by silex, which, by their perfectly horizontal position, their parallelism, theit continuities, and their frequency, indicate successive and almost periodical depositions.

Their respective distance varies according to the place : at Meudon they are about two metres (783. Eng. inches) from each other, and the space comprehended between any two beds of silex does not contain any detached pieces of this stone. At Bougival the beds are divided, and the silex is much less abundant.

The chalk which contains flints is not pure carbonated lime: it contains, according to M. Bouillon Lagrange, about Q.11 of magnesia and 0.19 of silex, the greatest part of which is in the state of sand, which we may separate by washing. The fossils found in it are not numerous, in comparison with those which we observe in the strata of coarse limestone (which almost immediately cover the chalk), but they are entirely different from these fossils, not only in the species, but epen in the genera. 
On adding those which we observed ourselves, to those which have been collected by $M$. Defrance, we extend to the number of fifty the various species of fossils with which we are acquainted in the chalk, of the soils which are the objects of our study.

All the species of these fossils have not been as yet determined, and we shall give in our subsequent detailed Memoirs their precise enumeration and determination: we shall content ourselves with saying on the present occasion, that we have found

Two lituolites.

Three vermiculites.

Some belemnites, which, according to $M$. Defrance, are different from those which accompany the ammonites of coimpact lime.

Some fragments of shells, which, from their tubular form and fibrous structure, cannot be referred to any other than the genus pinna; but if we were to infer from the thickness of these fragments the size of the individuals to which they must have belonged, we must conclude that these testacea must have been monstrous. We measured pieces 12 millimetres ( 47 inches) thick, while the thickness of the largest kinds of pinna known is only two millimetres ( 08 inches).

One muscle shell.

Two oyster ditto.

A species of the pinna genus.

A cranium.

Three anomites (térébratules).

One spirorlis.

Some ananchites, the crustaceous envelope of which has remained calcareous and assumed the sparry texture, while the middle part only is changed into silex.

Some porpytes.

Five or six different polytiers: one of them seems to belong to the genus caryophyllaa, and another to the genus millepora. This last is generally brown, and in the state of oxidated iron, resulting from the decomposition of pyrites.

Lastly, some teeth of squali.

We shall observe with M. Defrance, that there has not been found in chalk any univalve shell with a simple and regular spire. This fact is the more remarkable, as we meet with these shells in great abundance, some metres (39.38 inches) above the chalk, in calcareous strata also, but of a different structure.

Among the quarries and hills of chalk which we have visited, 
visited, we shall mention Meudon. The chalk is here covered by plastic clay and coarse limestone. The upper part of this mass is as it were broken, and presents a kind of rubble (brêche), the fragments of which are chalk, and the intervals clay.

The highest part of the mass of chalk appeared to us to be

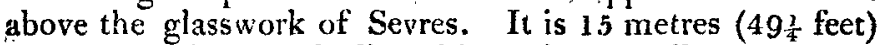
above the Seine. This disposition raises up all the strata of soil which surmount it, and seems at the same time to diminish their thickness. The mass of stone is sensibly inclined towards the banks of the river.

At Bougival, near Marly, the chalk is almost entirely exposed in some places, being only covered by calcareous otones of a very fine grain, but in fragments more or less large, and scattered in a marley sand, which is almost pure at the top.

Amidst these fragments we find geodites, of a yellowishwhite limestone, compact and fine grained, with sparry laminæ, and small cavities strewed with very small crystals of carbonated lime. The paste of these geodites contains a multitude of small spiral univalve shells; which seems to prove that th:s limestone does not belong to the chalk forpnation.

Among these geodites we found one, which presented a large cavity fringed with long and acute limpid crystals, upwards of two centimetres ( 79 inches) long.

Mechanical division alone informed us, that these crystals belonged to the species of sulphated strontian, and a more attentive examination of their form instructed us that they constituted a new variety. M. Hauy, to whom we communicated the circumstance, called it apotamous sulphated strontian.

These crystals presept rhomboidal prisms with four panes, the angles of which are the same with those of the prism of the unitary, or blunted (emoussée) varieties, \&cc., i. e. $77^{\circ} 2^{\prime}$ and $102^{\circ} 58^{\prime}$. They are terminated by pyramids with four faces and very acute. The angle of incidence of the faces of this pyramid on the adjacent panes is $161^{\circ} 16^{\circ}$. The faces are produced by a decrement by two ranges to the left and right of the angle $\mathrm{E}$ of the subtractive molecule. This is a law which had not hitherto been recognized in the varieties of sulphated strontian examined, to this day. Its sign will be $\mathrm{E}^{2}{ }^{2} \mathbf{E}$.

The crystals of strontian hitherto observed in the environs of Paris are extremely small, and fringe the sides of 
some of the geodites of strontian found in the green marles of gypsous formation ; but we have not as yet seen any of them so large and so well defined.

\section{Anticle II. Formation of Plastic Argil.}

Almost the whole surface of the mass of chalk is covered with a stratum of plastic clay which has some very remarkable common characters, although it presents sensible differences in various points.

This clay is unctuous, to the touch tenacious, and contains silex, but very little lime; so that it does not effervesce with the acids. It is even absolutely infusible in a porcelain furnace when it does not contain too great a proportion of iron.

It varies considerably in colour:-at Moret in the forest of Dreux, it is very white: at Montereau, Houdan, and Condé, it is gray : pure slate gray, slate gray mixed with red, and almost pure red, throughout the whole south of Paris, from Gentilly to Meudon.

This plastic clay is, according to its various qualities, employed in making porcelain, stone-ware, crucibles, or common red earthenware. It is never effervescent nor fusible. The red colour, the pyritous grains, the portions of silex, the small fragments of chalk, and the crystals of selenite which it sometimes contains, are the only defects found in it.

This stratum varies much in thickness : in some parts

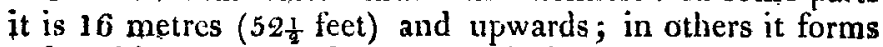
only a thin covering of one or two decimetres ( 4 or 8 inches).

It seems almost certain, that no marine nor terrestrial fossil is found in this clay, at least we have not seen any, either in the different strata we examined in their respective positions, or on the large heaps which we repeatedly examined, in the numerous manufactories in which it is used; besides which, the workmen who dig up this article in the south of Paris assured us, that they never found in it any shells, bones, wood, or vegetables.

Dolomieu, who discovered this same bed of clay be. tween the chalk and the coarse limestone in the elbow formed by the Seine in front of Rolleboise, says indeed that fragments of bituminous wood have been found in it, and that they have been even taken for coal; but he remarks, that these small woody portions have been found in pieces rolled down from the bank, which may have enveloped them at a period posterior to the primitive deposit of this clay. 
The places mentioned above prove, that this stratum of clay is very extensive, and preserves throughout its whole extent its principal characters of formation and position.

If we compare the descriptions we have given of the beds of chalk and beds of plastic clay, we shall remark: 1st, That not only we do not find in the clay any of the fossils met with in the chalk, but we do not ever find any fossil in it. 2d, "That there is no insensible passage between the chalk and the clay, since the parts of the bed of clay most adjacent to the chalk do not contain lime more than the other parts.

It appears to us that we may conclude from these observations, in the first place, that the liquid which has deposited the bed of plastic clay was very different from that which deposited the chalk, since it does not contain carbonated lime in any sensible quantity, and since none of the animals live there which inhabited the waters that deposited the chalk. Secondly, that there must necessarily have been a distinctly-marked separation, and perhaps even a long period of time between the deposit of the chalk and that of the clay, since there is no transition between these two kinds of soil. The kind of broken fragments of chalk and clay which we remarked at Meudon* even seems to prove that the chalk was solid when the clay was deposited. This earth is insinuated between the fragments of chalk produced on the surfacc of the chalky soil by the motion of the waters, or by some other cause.

The two kinds of soil which we have described have been produced, therefore, under completely different and even well-defined circumstances. They are the results of the most distinct and best characterized formations which can be found in geology, since they differ in their chemical nature, in the kind of stratification, and above all in the kind of fossils which we meet with in them.

\section{Article III. Formation of Sand and of coarse Limestone.}

The coarse limestone does not always immediately cover the clay, being frequently separated by a stratum of sand of various thickness. We cannot say whether this sand belongs to the formation of the calcareous earth, or to that of the clay. We have not found shells in it, in the few places where we have observed it, which would give it an

* Se page 48 
argillaceous formation; but the lowest calcareous stratum being generally sandy and always filled with shells, we do not as yet know if this sand be different from the first, or if it be the same formation. What would lead us to suppose that it was different is, that the sand next the clays which we have seen, is generally very pure, although of $\mathbf{a}$ red or blueish gray colour; it is refractory, and frequently in very coarse grains.

The calcareous formation reckoned from this sand is com posed of alternate strata of coarse limestone, more or less hard, of argillaceous marle, and even leafy clay in very thin strata, and of calcareous marle; but it must not be supposed that these various strata are placed there by chance, and without following some general law: they uniformly follow the same order of superposition in the considerable extent of soil which we have examined. In some places several of them are entirely wanting, or are very thin; but that which was the lowest in one district never becomes the uppermost in any other.

This constancy in the order of superposition of the thinnest strata, and over an extent of 12 myriametres ( $74 \frac{1}{2}$ miles) at least, is in our opinion one of the most remarkable facts which we have established. From this there ought to result most interesting consequences to the arts and to geology.

The means which we have employed for ascertaining, in the midst of so great a number of calcareous beds, a stratum already observed in a very distant district, is taken from the nature of the fossils contained in each stratum, these fossils being generally the same in the corresponding strata, and present differcnces of species sufficiently remarkable between one system of strata and the other. This is a mark which has not as yet deceived us.

It must not be thought, however, that the difference between one stratum and another is equally well marked with that between the chalk and the limestone. If this was the casc, we should have an equal number of distinct formations; but the characteristic fossils of one stratum become less numerous in the next superior stratum, and disappear completely in the rest, or are replaced gradually by new fossils which had not as yet appeared.

We now proceed to point out (following the same course) the principal systems of strata which may be observed in the coarse limestone. In the detailcd Memoir about to be published will be found the complete description, stratum by stratum, of the numerous quarries which we have observed in order to procure materials for our publication. 
The lowermost strata of calcareous formation are the best characterized: they are very sandy and frequently even, rather sandy than calcareous. When they are solid, they are decomposed and fall into dust on the first exposure: this kind of stont therefore is not fit to be used.

The shelly limestone which composes it, and even the sand which sometimes supplies its place, almost always contain green earth in powder or in small grains. This earth, from our experiments, appears to be analogous to terra veronica. It owes its colour to iron; it is found in the lower strata only: we do not find it in the chalk, in the clay, nor in the middle or upper calcareous strata, and we may regard its presence as a certain indication of the proximity of plastic clay, and consequently of chalk. But what characterizes still more particularly this system of strata, is the prodigious quantity of fossil shells which it contains. In order to give an idea of the number of species which these strata contain, it will be sufficient to say that M. Defrance has found more than six hundred species, all of which have been described by M. Lamarck.

We have to remark that most of the shells of the lowest of these strata are much further removed fiom the present existing species, than those of the upper strata. We shall mention among the fossils peculiar to these lower strata, periwinkles, oysters, muscles, pinnæ, calyptreæ, pyrulæ, large tellines, terebellæ, porpytes, madrepores, and particularly nummulites and fungites.

Such are the names of the most remarkable shells in this stratum : we ought to remark that it was not in the depôt of Grignon alone that we gathered the specimens we have described; such examples would not have characterized the system of strata which we wish to make our readers acquainted with : we chose them from the quarries of Sevres, Meudon, Issy, Vaugirard, Gentilly ; in the strata of Guespelle; in those of Pallery near Chaumont, \&c.

It is in this same stratum that we find the camerines. They are either by themselves or mixed with madrepores and the preceding shells. They are always the lowest, and consequently the first which are deposited on the chalky. formation; but this is not the case every where. We have found some of them near Villers-Cotteret, in the valley of Vaucienne; and at Chantilly on the declivity of the mountain. They are mixed here with shells in good preservation, and with coarse grains of quartz, which, together, make it a kind of puddingstone, on Mount Ga- 
nelon near Compiegne, and Mount Ouin near Gisors, \&c.

Another character peculiar to the shells of this stratum is, that they are mostly very entire and well preserved, being easily detached from their rock, and some of them have preserved their pearly state. In all the preceding places, and in others, this is less remarkable; because we ascertained that the sandy calcareous strata, which contain these shells, immediately follow the plastic clay which covers the chalk; and it is by these multiplied observations that we recognized the generality of the scale which we have laid down.

The other systems of strata are less distinct, and we have not as yet been able to arrange the numerous obserrations which we have made, in order to establish with precision the steccession of the different fossils which ought to characterize them. We can announce, however, that, from our inspection of the quarries to the south and west of Paris, from Gentilly to Villepreux and Saint-Germain, the strata above those which we have described succeed each other in the following order.

1. A soft stratum frequently of a greenish colour, this is called the green bank by the workmen. It frequently exhibits on its lower surface brownish marks of leaves and stalks of vegetables.

2. Gray or yellowish strata, sometimes suft, sometimes very hard, and containing chiefly roundish venuses, campreys, and particularly tuberculated cerites, which last are sometimes in prodigious quantity. The upper and middle part of this stratum, frequently hard, is a very good stone building, and is known by the name of the rock.

3. Lastly, and towards the upper part, a stratum, not thick but hard, which is remarkable from the prodigious quantity of small long and striated tellines which it presents in its seams. These tellines are laid horizontally, and closely wedged against each other. They are generally white.

Above these last strata of coarse limestone we find hard calcareotis marles divided into fragments, the faces of which are generally covered with a yellow coating and with black dendrites. These marles are separated by soft calcareous marles, by argillaceous marles, and by calcareous sand, which is sometimes agglutinated, and it contains horny silex with horizontal zones. We refer to this system the stratum of the quarries of Neuilly, in which we find crystals of quarts and rhomboidal crystals of variegated carbonate of lime. 
But what characterizes more particularly this last system of strata of calcareous formation, is the absence of every shell and of every other fossil.

It results from the observations which we have related:

1st, That the fossils of coarse limestone have been deposited slowly and in a calm sea, since these fossils are deposited by regular and distinct strata; that they are not indiscriminately mixed, and that most of them are in a state of perfect preservation, however delicate may be their texture; the points of the prickly shells being very often unbroken.

$2 \mathrm{dly}$, That these fossils are entirely different from those of the chalk.

3dly, That in proportion as the strata of this formation were deposited, the number of the species of shells diminished until no more are found. The waters which formed these strata either have not eontained any, or have lost the property of preserving them.

There can be no doubt that things went on very differently in these seas from what they do at present in the waters of the present day; where no strata are formed, the species of shells found in them are always the same in the same regions; we do not find, for example, since we began to fish for oysters on the shores of Concale, that this kind of shell-fish has been replaced by other kinds.

\section{Art. IV. Gypsous Formation.}

The soil which we are now about to describe, is one of the clearest examples of what is meant by the word formation. Here we find strata very different from each other in their chemical nature, but evidently formed together.

The soil which we call gypsous is not composed of gypsum alone, it consists of alternate strata of gypsum and of argillaceous and calcareous marle. These strata have pursued an order of superposition, which has been always the same, in the great gypsous girdle which we have studied. and which extends from Meaux to Triel and Grisy. Some strata are wanting in certain districts ; but those which remain are always in the same respective position.

The gypsum is placed immediately above the limestone, and it is impossible to donbt this superposition. The position of the gypsum quarries of Clamart, Meudon, and Villed'Avray, is abnve coarse . limestone wrought in the same places; that of the quarries of the mountain of Triel, the superposition of which is still more evident; lastly, a well

Vol. 35. No. 141. Jan. 1810.

D dug 
dug in the garden of M. Lopez at Fontenay-aux-Roses, which first passed through the gypsum, and afterwards the limestone, are ample proofs of the position of the gypsum on the limestone.

The gypsous hillocks have a peculiar appearance, which renders them conspicuous at a great distance : as they are always placed upon the limestone, they form on the higher eminence a kind of second conical or elongated hillock, always distinctly marked.

We shall exhibit the details of this formation, by taking, as an example, the mountain which presents the most complete collection of strata; and although Montmartre has been already well described, it is still the best and the most interesting example that can be selected.

We have recognized, both at Montmartre and on the hillocks which seem to form the continuation of this eminence, three masses of gypstum. The lowermost is composed of alternate and thin strata of gypsum, frequently selenitous, of solid calcareous marles, and of very scaly argillaceous marles. It is in the former that we chiefly see the coarse crystals of lenticular yellowish gypsum, and it is in the latter that we find the menilite silex. We are not acquainted with any fossil in this mass, whicn is the third, of the quarries.

The second or intermediate mass differs from the foregoing only because the gypsous beds are thicker, and the marley strata are less numerous. We ought to remark that among these masses, that which is argillaceous, compact, and of a marbled gray appearance, serves for building-stone. It is chiefly in this mass, that fossil shell-fish have been seen. No other fossils, however, are found in it; but sulphated strontian has lately been discovered in it, in scattered fragments, in the lower part of the marble-like marle.

The superficial mass, which the workmen call the first, is in every respect the most remarkable, and the most important. It is, besides, much more extensive than the rest, since it is in some places 2.5 metres ( 82 feet) thick, interrupted only by a small number of marley strata; and in some places, as at Dammartin and Montmorency, it is situated almost imme diatrly under the vegetable earth.

The lowermost beds of gypsum in this first mass contain silex. The silex and gypsum scem as if mutually dissolved in each other. The intermediate beds are naturally divided into cuarse prisms, with several planes, which $M$. Desmarets has drawn extremely well. They are called the high pillars. Finally, the uppermost strata 
are interlaid with marle: they are but thin, and are alternated with strata of marle; there are gencrally five such, which are continued to grear distances.

But these facts, which are already known, are not the most important : we mention them only that they may be brought under view at one glance. The fossils which this mass contains, and those contained in the marle that covers it, present observations of a different interest.

It is in this first mass that we daily find the skeletons of unknown birds and of quadrupeds, which have been already described by one of us (M. Cuvier) in a separate memoir*. To the northward of Paris they are in the gypsous mass itself; here they have preserved their solidity, and are only surrounded by a very thin stratum of calcareous marle; but in the quarries to the southward, they are frequently in the marle which separates the gypsous strata: they have then a great degree of friability. We shall not revert to the manner in which they are situated in the mass; upon their state of preservation, species, \&c. these objects having been sufficiently developed in the Memoirs which we have mentioned. We have also found in this mass, bones of tortoises and skeletons of fish.

But what is much more remarkable, and much more important from the consequences that result from it, is, that we find, although very rarely, fresh-water shells. Indeed, one only is sufficient to demonstrate the truth of the opinion of Lamanon and some other naturalists, who think that the gypsums of Montmartre, and of the other hillocks of the basin of Paris, have been crystallized in fresh-water lakes. We shall relate new facts in confirmation of this.

In the last place, the superficial mass is essentially characterized by the presence of the skeletons of manimiferæ. These fossil bones serve to point it out where it occurs in isolated masses; for we have never been able to discover that they have been found in the lower masses.

Above the gypsum are placed strong strata of marle, sometimes calcareous, and sometimes aryillaceous.

It is in the lower beds, and in a white and friable calcareous mass, that we have at various times met with trunks of palin-trees converted into silex. They were lying flat, and of a large bulk. It is in this same system of strata that we found (but only at Romainvilte) shells of the genus lymnea and planorbes, whicb seem to differ in no respect from the species now existing in our marshes. One of us has already conmunicated this important fact to the class.

* Published in Anzales du Muséum.

D 2 
It proves that these marles are of fresh-water formation, like the gypsums which they cover.

Abore these white marles are also seen very numerous and frequently thick argillaceous or calcareous marles, in which no fossil has been as yet discovered.

We afterwards met with a small bed six decimetres (24 inches) thick, of a scaly yellowish marle, which contains towards its lower part scraps of earthy sulphated strontian, and a little above a thin bed of small elongated tellines, which are lying flat, packed closely into each other. This bed, which seems to be unimportant, is nevertheless remarkable in the first place from its great extent : we have observed it over a space more than ten leagues (27 $\frac{1}{2}$ miles) long and more than fuur ( 11 miles) broad, always in the same place and of the same thickness. It is so thin, that we ought to know precisely where it lies, in order to find it out. Secondly, because it serves as a limit to the fresh-water formations, and indicates the sudden commencement of a new marine formation.

In fact, all the shells which we meet with above this bed of tellines are also marine.

We find at first, and immediately afterwards, a strong and constant stratum of greenish argillaceous earth, which from its thickness, colour, and continuity, may be recognized at a great distance. It serves as a guide to the tellines, since it is beneath it that we find them. It contains no other fossil, but merely argillo-calcareous geodites and scraps of sulphated strontian. This earth is employed in the manufacture of coarse pottery.

The four or five beds of marle which succeed the green earths are not thick, nor do they seem to contain fossils; but these beds are immediately covered by a stratum of yellow argillaceous marie, which is strewed with fragments of sea shells which belong to the genera cerites, trochi, mactres, venus, cardium, \& c. We also meet with fragments of the bones of a thornback.

Almost all the beds of marle which succeed the.latter present fossil sea shells, but they are bivalves only; and the last strata (those which are immediately below argillaceous sand) contain two very distinct oyster beds. The first and lowermost is composed of very thick large oystershells : some of them exceed a decimetre ( 4 inches) in length. Afterwards comes a stratum of whitish marle, without shells, then a second very strong oyster bed, but subdivided into several beds. These oyster shells are brown, much snaller and thinuer than the above. These last beds of ovsters are very frequent, and we have not perhaps seen them twice 
fail, in the numerous hillocks of gypsum which we have examined. The gypsous formation is frequently terminated by a mass, more or less thick, of argillaceous sand, which contains no shells.

Such are the strata which generally compose the gypsous formation. We were at first led to divide it into two, and to separate the history of the marine marles of the top from those of the gypsum, and of the fresh-water marles at the bottom ; but the strata are so similar to each other, and accompany each other so constantly, that we have ihought: it right merely to point out this division without making it in reality.

It now remains to say a few words, as to the principal differences presented by the billocks which belong to this formation. The gypsous hillocks form a kind of long and broad zone directed from the south-east to the north-east, over a breadth of about six leagucs ( $16 \frac{\mathrm{i}}{2}$ miles). It seems that in this zone it is only the eminences of the centre which present distinctly the three masses of gypsum. Those of the edges, such as the plaster quarries of Clamart, Bogneux, Antoni, Mont Valerian, Grisy, \&c., and those of the extremities, such as the plaster quarries of Chelles and Triel, possess only a single mass. This mass seems to us to be analogous to that which the workmen call the first, $i$. $e$. the most superficial, since we find in it the fossils of the mammiferæ which characterize it ; and since we do not find, in its marles, those coarse and numerous crystals of Ienticular gypsum which we observe in the marles of the second and of the third mass.

Sometimes the marles above, are almost entirely wanting; sometimes the gypsum itself is totally wanting, or reduced to a thin bed. In the first case the formation is represented by the green marles, accompanied with strontian. The gypsous formations of the park of Versailles near Saint Cyr, those of Viroflay, are in the former state, and those of Meudon and Villend'Avray are in the latter.

We ought to mention here what has been said of another work*, namely, that the gypsous soil of the environs of Paris cannot be referred with accuracy to any of the formations described by $M$. Werner or his followers. We have on the above occasion assigned our reasons, which it is needless to repeat.

* Brogniart, Minéralogie, tom. i. p. 177.

D 3

ART. 


\section{Ant. V. Formation of Sea-Sand and of Freestone.}

This soil is not extensive, and seems to form a succession to the formation of the marles of gypsum. We should even have brought them together, if it had accompanied them as constantly as the marles accompany the gypsum, and if it had not been frequently separated by a considerable argillaceous mass, stripped of every fossil, and very different in its nature from that which we are now about to describe.

What we have said, shows that this formation generally covers the gypsous formation. It consists in beds of siliceous sand, frequently very pure and agglutinated into freestone, which contains sea shells of various kinds, and all of them of the same kind as those of Grignon. We have here recognized the same oysters, the same calyptreæ, the same tellines, and the same cerites. Somctimes the shells thernselves exist, and are in a calcareous state, while in other places nothing remains of them but the external impressions or moulds.

We found this freestone and sea sand on the top of Montmartre, at Romainville, at Saint Prix near Montmorency, Longjumeau, \&c. In these last we also remark fossil balani.

We camnot help reflecting, when looking at these freestones, filled with the same shells as those of Grignon, on the singular circumstances that must have presided over the formation of the strata we have examined. On beginning with the strata after the chalk, we may represent to ourselves in the first place a sea which has deposited an immense mass of chalk and mollusci of a particular species. This precipitation of chalk and the shells which accompany it, suddenly ceases. Strata of a totally different nature succeed it, and nothing else is then deposited but clay and sand without any organized borly. Another sea returns: this last contains a prodigious quantity of testaceous mollusci, all of them different from those of the chalk. It forms at bortom thick beds, in a great measure composed of the testaceous envelopes of these mollusci; but this production of shells gradually diminishes, and also suddenly ceases. The soil secms then to have been covered with fresh water; alternate strata of gypsum and of marle are formed, which surround both the bones of the animals which these waters nourished, and the bones of those which liyed on their shores. 
The sea seems to have returned a third time, producing some species of bivalve and turbinated shells; but very soon after the same sea gives birth to oysters only. Lastly, the productions of the lowermost second sea reappear, and we find on the top of Montmartre the same shells which were found at Grignon, and in the bottom of the quarries at Gentilly and Meudon.

\section{ART. VI. Formation of siliceous Limestone.}

The formation of which we have spoken is parallel, as it were, to that of the siliceous limestone. It is neither situate above nor below, but on one side of it, and seems to retain its place in the immense extent of soil which it covers to the west and south-west of Paris.

This soil is placed immediately above some plastic clays. It is formed of distinct beds of limestone, sometimes soft and white, and sometimes gray and compact, and very fine grained, penetrated with silex which seems to have filtered in every direction. As it is often porous, this silex, by filtering into the cavities, has fringed their sides with tufted stalactites (mamelonées) variously coloured, or with very short crystals of quart $z$, almost without any prism, but clear and limpid. This disposition is very remarkable at Champigny. The compact limestone thus penetrated with silex yields, on being burnt, lime of a very good quality.

But the distinguishing character of this singular formation, which no person had remarked before we did, although it covers a considerable extent of soil, is this, namely, that it contains neither marine nor fluviatile fossils; at least we have not been able to discover any in the great number of places where we have examined it with the most scrupulous attention.

It is in this soil that we find the stones known by the name of burrstones (meulieres) : these stones, the origin, formation, and situation of which were unknown to most mineralogists, seem to be the siliceous impression of the siliceous limestone. The silex, stripped of its calcareous parts by an unknown cause, must have left, and does in fact leave, porous but hard masses, the cavities of which still contain argillaceous marle, which present no trace of stratification. We have made true artificial burrstones by throwing this siliceous limestone into nitric acid. We shall explain in our full Memoir the various districts of soil which ate formed of this limestone. We shall finish its general 
history by saying, that it is frequently exposed on the surface of the earth, but frequently also it is covered with argillaceous marles, with freestone without shells, and finally with alluvial soil. Such is the nature of the soil of the forests of Fontaineblean.

\section{ARr. VII. Formation of Freestone without Shells.}

The freestone without shells, in whatever place it is found, is always either the last or the penultimate formation. It constantly covers the rest, and is never covered, except by the formation of alluvial soil. Its beds are frequentls very thick, and mixed with beds of sand of the same nature. The sand which supports the upper beds, has been sometimes washed out by the water; the beds are then broken, and have rolled over the flanks of the hillocks which they formed : of this kind are the freestones of the forest of Fontainebleau, of Palaiseau, \&c.

Not only do this freestone and sand contain no fossils, but they are frequently very pure, and furnish sands much esteemed in the arts, and which are gathered at Etampes, Fontainebleau, Aumont, \&c.

They are sometimes, however, either altered by a mixture of argil, or coloured by oxides of iron, or impregnated with carbonated lime which has penetrated them by infiltration when they are covered by the calcareous soil of fresh water: this is still the case with the freestone of several parts of the forest of Fontainebleau.

\section{Arr. VIII. Formation of the Fresh-water Soil.}

This formation constantly covers all the foregoing. The rock which has resulted from it resembles, in point of structure and other external properties, siliceous limestone, $i$. e. it is sometimes compact, sometimes white and soft, but almost always penetrated with siliceous infiltration. The same silex, sometimes opaque and yellowish, sometimes brown and translucid like pyromatic silex, in some places completely fills the place of the limestone: finally, this formation gives, like the sixth, burrstones, the origin of which has one and the same cause.

What exclusively therefore characterizes this formation is, on the one hand the presence of shells, which are evidently of fresh-water origin, and similar in every respect to those which we find in our marshes. These shells are lymnea and three kinds of planorbes. We also find in this forma- 
tion small round hollow bodies (canelés) which M. de Lamarck has called gyrogonites. We are not acquainted with any analogous existing species : but their position informs us, that the organized body of which they formed part lived in fresh water.

The second character of this formation is the facility which the limestone composing it has of being dissolved in water, however hard it may seem at the moment of its being taken out of the quarry. Hence it is used as marle, fertilizing the soil at Trappe near Versailles, and other places.

We refer to this formation, but rather with hesitation, the sands of the eminences which contain wood and parts of vegetables changed into silex. We were led to make this junction, by observing the siliceous wood and vegetables, which we find towards the top of the hillocks of Longjumeau. The same sand which contains these vegetables, also contains silex filled with coarse lymnex and planorbes.

The fresh-water soil, although always superficial, is not found in every situation, but rather towards the summits of the eminences, and on the great platforms as well as in the bottoms of the valleys; if it exists in the latter situations, it has been covered by the soil which constitutes the ninth and last formation. Besides, it is extremely common throughout the whole of the environs of Paris, and probably at distances much further off than we have visited. It seems to us astonishing, that so few naturalists have paid attention to the subject; we know no other person than M. Coupé who has mentioned it.

The presence of this soil pre-supposes, in the fresh water which then existed, properties which we no longer find in those now in existence. The waters in our marshes and lakes deposit nothing but friable slime. We have not remarked in any of them the property possessed by the fresh waters of the old world to form thick depôts of yellowish and hard limestone, of white marles and silex, frequently very homogeneous, enveloping all the ruins of the organized bodies which lived in these waters, and even bringing them to the siliceous and calcareous nature of their envelopes.

\section{Article IX. Formation of Alluvium (Atterissement).}

Not knowing how to designate this formation, we have given it the name of alluvium, which indicates a mixture of matter deposited by fresh water. In fact, the slime of al- 


\section{Mineralogical Geography of the Environs of Paris.}

luviation is composed of sand of all colours, marle, or evert of the mixture of these three substances, impregnated with carbon, which gives it a brown and even black appearance. It contains rounded fints ; but what characterizes it more particularly is, the remains of the huge organized bodies with which it abounds. It is in this formation that we find large trunks of trees, bones of elephants, of oxen, antelopes, and other large mammiferæ.

It is also to this formation that we may ascribe the accumulation of flints at the bottom of valleys ; and probably also those of some plains, such as the Bois de Boulogne, the plain of Nanterre at Chateu, and certain parts of the forest of St. Germain.

This alluvium is not only found in the bottom of our present valleys, but it has covered valleys or excavations which have been since filled up. We may observe this arrangement in the deep cutting made near Seran, for the canal of Ourque. This cutting shows an ancient cavity, filled with the substances which compose the alluvium, and it is in this kind of marshy bottom that we have found bones of elephants and large trunks of trees.

It is to the existence of these ruins of organized bodies which are not yet entirely decomposed, that we ought to ascribe the dangerous and frequently pestilential emanations which are extricated from these soils, when they are stirred up for the first time since the period of their formation; for it is the same with this formation, which appears to be so modern, as with all those others which we have examined. Although very modern in comparison with the other soils, it is still anterior to any historic æra; and we may say, that the alluvium of the old does not in any respect resemble that of the present world, since the wood and animals found in them are entirely different, not only from the animals of the countries where they are found deposited, but also from all those hitherto known. 